\title{
Sociology Study Development with Problem Based Learning Approach in Class XI Students at SMAN 1 Jakarta
}

\author{
Dias Yuditia Pribadi ${ }^{1}$, Eveline Siregar ${ }^{2}$, Dwi Kusumawardani ${ }^{3}$ \\ Teknologi Pendidikan PPS 2020, Universitas Negeri Jakarta, Indonesia \\ dias.yuditia84@gmail.com
}

\begin{abstract}
This study aims to develop Sociology Subjects with Problem-Based Learning Approaches in Class XI Students at SMAN 1 Jakarta. This research is a type of research and development. The model used in this study is the Instructional Development Model (MPI). This research was conducted at SMAN1 Jakarta with the research subject, namely students of class XI IPS. The data were collected using interviews, instrument tests in the form of pre-test and posttest questions, and documentation. The results showed that from the expert test consisting of material, media and instructional design experts it can be stated that the learning design of Sociology Subjects with a problem-based learning model approach is feasible to use.
\end{abstract}

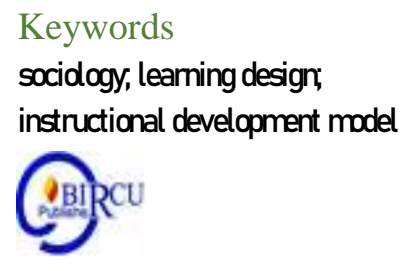

Keywords

socidogy, learning design instructional development model

\section{Introduction}

The learning process requires the right learning model and the right method. Mistakes in using learning models can hinder the achievement of the desired educational goals. Another impact is the low ability of students to reason in a lesson. This is because in the learning process in the classroom students are less involved in optimal situations for learning, learning tends to be teacher-centered, the teacher becomes. In addition, students are less trained to analyze existing problems, students rarely submit ideas to answer questions about the process of solving the questions posed by the teacher. Ivor K. Davis argues that "one of the tendencies that is often overlooked is forgetting that the essence of learning is student learning and not teacher teaching" (Rusman, 2012).

At this time, the Sociology subject was identified as a "rote" subject by both teachers and students. Sociology subjects are considered nothing more than a collection of concepts and theories that must be memorized outside the heads of students so that they are meaningless. This assumption arises because many of the learning and evaluation processes carried out by sociology teachers only lead to rote memorization. Whereas memorization is the result of learning in the lowest cognitive domain in Bloom's taxonomy.

The sociology learning process that leads to memorization is proven ineffective, in fact what happens in the field of sociology learning outcomes is generally still low. The results of the 2018/2019 academic year UN released by the Ministry of Education and Culture (https://hasilun.puspendik.kemdikbud.go.id, 2020) confirm this. 

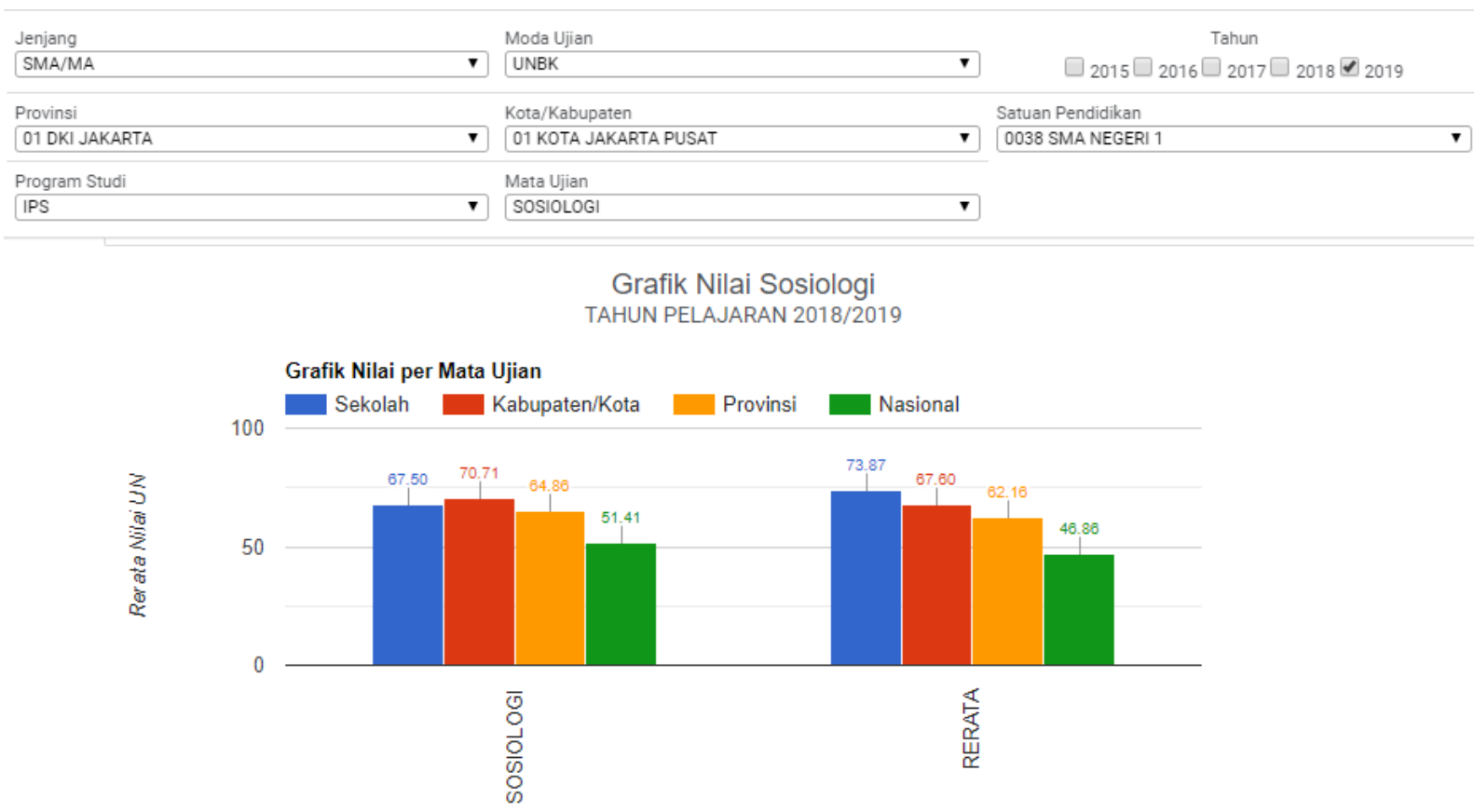

Figure 1. Grafik Rerata UN Sosiologi SMAN 1 Jakarta

The sociology value of SMA Negeri 1 Jakarta from the 2018/2019 academic year is still below 75 because the sociology learning process that takes place at SMA Negeri 1 Jakarta still shows learning that leads to conventional learning, such as the learning process is still taking place in one direction, namely the teacher is more dominant in conveying information It is recommended that students and students master the learning material by memorizing existing concepts which will later be presented one by one in front of the class.

The unavailability of sociology learning designs that are specific to the application of problem-based learning models is an obstacle for teachers and students in achieving learning objectives, even though the application of problem-based learning models in sociology subjects will involve students to be able to play an active role with teacher guidance, so that students' abilities are increased in relating the concepts learned to the real problems around them. Based on the background of the problem above, the researcher is interested in developing a learning model with the title "Development of Sociology Subjects with a PBL Approach in Class XI Students at SMAN1 Jakarta".

\section{Review of Literatures}

\subsection{Development Style}

The definition of development research according to Borg \& Gal is a process used to develop and validate research products. This study followed the steps in a cycle. This research step or development process consists of studying the product research findings to be developed, developing products based on these findings, conducting field trials according to the background in which the product will be used, from revising the results of field tests. Development research according to Seels \& Richey is defined as follows: "development research, as opposed to simple instructional development, has been defined as the systematic study of designing, developing and evaluating instructional programs, processes and products that must meet the criteria of internal consistency and 
effectiveness. '. Based on this definition, development research as distinguished from simple learning development is defined as a systematic study to design, develop and evaluate programs, processes and learning outcomes that must meet the criteria of consistency and effectiveness internally (Punaji Setyosari, 2016).

\subsection{Problem Based Learning Model}

Problem-based learning is based on cognitive psychology theory, especially Piaget and Vigotsky's theory (constructivism). According to Constructivism theory, students learn to construct their knowledge through interaction with their environment. Problem-based learning (PBL) can make students learn through structured real world problem solving efforts to construct student knowledge. This learning requires students to actively carry out investigations in solving problems and the teacher acts as a facilitator or guide. Learning will be able to form higher order thinking skills and increase students' ability to think critically (Ridwan, 2014).

In contrast to discovery learning (inquiry-discovery) which emphasizes more on academic problems. In problem-based learning, problem solving is defined as a process or effort to get a real-life task or situation accomplished as a problem by using known rules. So, problem-based learning focuses more on real-life problems that are meaningful to students.

\subsection{Critical Thinking}

Critical thinking is a systematic process that allows students to formulate and evaluate their own beliefs and opinions. In addition, he argues that critical thinking is an organized process that allows students to evaluate evidence, assumptions, logic and language that underlie other people's statements (Elaine, 2012).

Using argument analysis and giving birth to new insights from the interpretation of facts, situations, problems and circumstances through deductive or inductive reasoning are the basis for critical thinking. In critical thinking, a person's mind must be open in determining decisions made based on the facts they have. Facione emphasized that critical thinking is a decision making on what to do and believe through a way of reflection. In line with Facione's opinion, Ennis argues that critical thinking is the focus of the mind on reflection to determine what should be done and believed. Critical Thinking or critical thinking can also be interpreted as an art in analyzing and evaluating with a view to improving it (Desmita, 2006) 


\section{Research Methods}

Researchers in this study used the instructional development model (MPI) development procedure developed by Atwi Suparman.

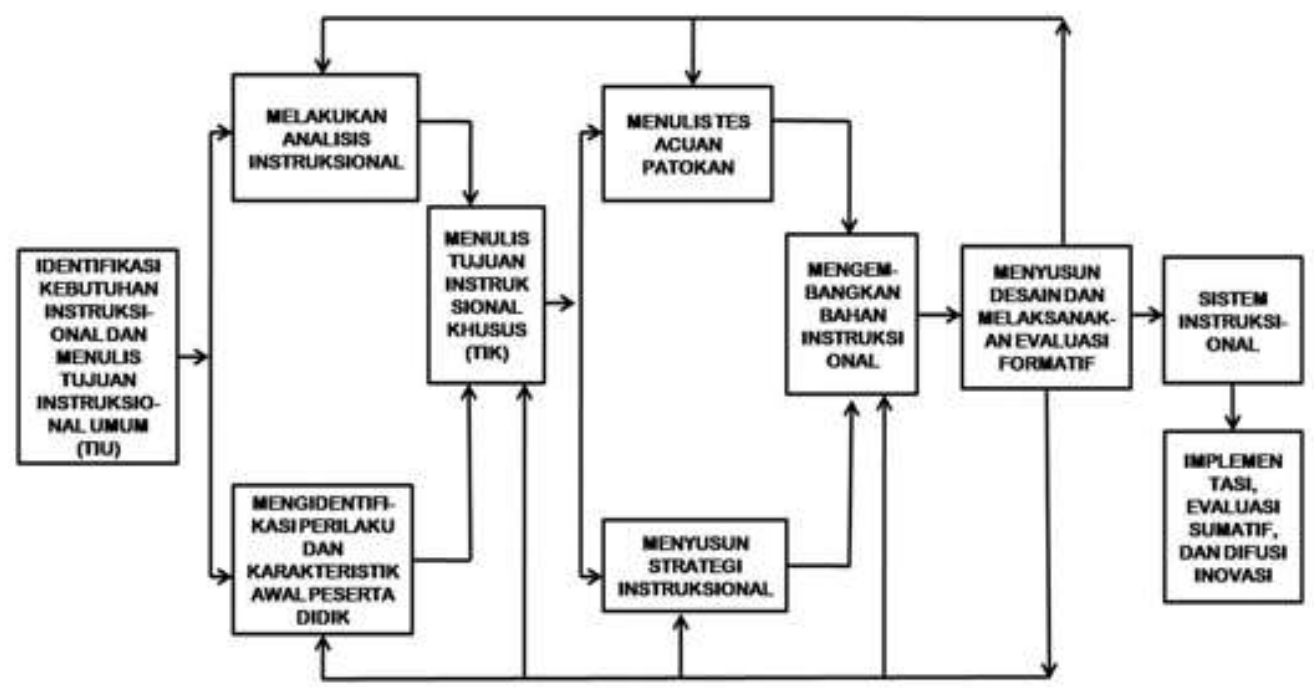

Figure 1. Skema MPI

\subsection{Development Procedure}

\section{a. Identifying Instructional Needs}

Instructional activities in Atwi Suparman (Suparman, 2014), are intended to identify gaps between the current condition and what it should be. In general, the information that is sought in the process of identifying instructional needs is the current competence of students to be compared with the competencies they should have.

Researchers in identifying learning needs conducted structured interviews with teachers and students. Interviews were conducted to identify learning needs including learning objectives, learning models, learning media, learning tools, knowledge of problem-based learning models, learning outcomes and the learning process in class. Based on the results of the interview, it was obtained a description of the competency gap of students now, with the expected conditions.

After analyzing the needs of the researcher, the researcher can identify the deficiencies that occur in the sociology learning process at SMAN 1 Jakarta. These deficiencies will become a benchmark in the preparation of general instructional goals so that students' critical thinking abilities increase.

\section{b. Write Down a General Instructional Objective}

From the activity of identifying instructional needs, the answer was obtained that solving the problem of the gap between the current state and the one expected was the implementation of instructional activities. The goal is the achievement of competencies that have never been studied or have not been carried out properly by students. These learning outcomes are called general instructional goals

The activity of formulating general instructional objectives aims to produce directions for sociology subjects that will be developed by researchers for deficiencies that occur during the current implementation of sociology learning. The objectives set are expected to solve the learning problems faced by students. 


\section{c. Perform Instructional Analysis}

Instructional analysis in Atwi Suparman (Suparman, 2014) is a process of describing general competencies into sub-competencies, basic competencies or special competencies that are structured logically and systematically.

Researchers conducted an instructional analysis in this study by conducting discussions with teachers and vice principals in the curriculum field to determine the subjects to be discussed in the learning process that referred to general learning objectives. The result of the learning analysis step is a sub-competency map that shows the most basic sub-competency arrangement to the highest competency as formulated in TIU.

\section{d. Identifying Behavior and Early Characteristics of Students}

At this stage the researchers conducted unstructured interviews with the vice principal in the field of curriculum and obtained information about students through documents owned by the school. The stage of identifying student behavior and characteristics is carried out with the aim of obtaining information about the starting point or beginning of lessons that must be given to students, general characteristics of students, experience, motivation, location of residence, access to communication channels / information technology media. This information is needed because it is estimated that it can affect the success rate of achieving instructional goals so that it needs to be taken into account in the instructional design process.

\subsection{Writing Specific Instructional Goals}

Special Instructional Objectives (ICT) in Atwi Suparman (Suparman, 2014) are a translation of specific instructional objectives. Foreign literature refers to them as objectives, or enabling objectives to differentiate them from general instructional objectives, goals, terminal objectives, which mean General Instructional Objectives (TIU).

Researchers in formulating specific learning objectives hold discussions with material experts and sociology subject teachers to produce specific learning objectives formulations that are in accordance with this research. The results of the discussion were in the form of formulation of specific learning objectives

\section{a. Develop Learning Outcomes Assessment Tool}

Researchers in this study will use a benchmark reference test as a tool for assessing learning outcomes. Benchmark reference tests are used to assess and measure the level of mastery of each student against the competencies listed in specific learning objectives. At this stage, the researcher made a grid and question instruments which were discussed with the sociology subject teacher. The results of this stage are in the form of grids and items or learning outcomes tests that will be given to students

\section{b. Develop Instructional Strategies}

Gagne, Wager, Colas and Keller in Atwi Suparman (Suparman, 2014) explain the notion of Instructional strategy as a tool or technique available for instructional educators and designers to design and facilitate learning. Researchers in compiling and developing instructional strategies hold discussions with teachers of sociology subjects. The results of the learning strategy are in the form of a syllabus and a lesson plan design. While Simorangkir and Sembiring (2018) stated that Education that is carried out from time to time is always changing in accordance with the times. Therefore, teachers as learning managers are required to be more creative and innovative in order to make learning outcomes more optimal. 


\section{c. Develop Instructional Materials}

Researchers at this stage developed instructional materials in the form of material summaries, media presentations (powerpoints), video lessons and guidelines for teachers and students to be used in sociology learning with a problem-based learning approach. In developing this learning material, the developer conducts discussions with the sociology subject teacher to produce instructional materials that match the learning objectives.

\section{d. Designing and Implementing Formative Evaluations}

Formative evaluation is carried out to assess the quality and efficiency of the developed product. The products developed by researchers were tested for feasibility by expert reviews (material experts, learning design experts, and media experts) and tested for effectiveness through one to one evaluation, small group trial and field test.

\section{Results and Discussion}

The sociology subject learning design with the Problem Based Learning approach developed by the researcher is made according to the needs of students and teachers in schools and is developed by following the steps of the instructional development model. A good learning design will make it easier for teachers and students to achieve learning goals.

Based on the results of identification of needs, there is no yet available learning plan for sociology subjects that uses a comprehensive and good quality PBL approach, even though a sociology learning design that supports critical thinking processes and the ability to solve problems is needed in the world of education.

The Learning Design for Sociology Subjects with the PBL Approach is prepared based on the suitability of the approach to the material that has been selected. This approach is expected to be able to make students accustomed to thinking critically or in sociology, known as sociological imagination, sensitive and able to provide solutions to social problems in their daily life in society. Making cases of social problems that are contextual and close to the lives of students will bring out meaning when they apply them in learning.

The learning design of sociology subjects with the PBL approach developed by researchers has been through due diligence by expert reviews in terms of material, learning design and media. Based on the data from the feasibility test results, the design of the Sociology Subject Learning Design with the PBL approach developed by the researcher is appropriate for use in the sociology learning process in schools with the following details:

\begin{tabular}{|c|l|}
\hline \multicolumn{2}{|c|}{ Expert of Mathery } \\
\hline Before evaluation & \multicolumn{1}{|c|}{ After of evaluation } \\
\hline \multirow{3}{*}{ TIU contains two verbs } & $\begin{array}{l}\text { Changing TIU to after participating } \\
\text { in sociology learning with a } \\
\text { problem-based learning approach, } \\
\text { students will be able to provide } \\
\text { solutions to solving social problems }\end{array}$ \\
using various sociological concepts \\
and factual data
\end{tabular}




\begin{tabular}{|c|c|}
\hline & $\begin{array}{l}\text { - Analyze the social problems } \\
\text { of poverty } \\
\text { - Analyze the social problems } \\
\text { of crime } \\
\text { 2. Change some of the ICT using the } \\
\text { verb explain to idenfy and predict. }\end{array}$ \\
\hline \multicolumn{2}{|c|}{ Expert of lesson desain } \\
\hline Before evaluation & After evaluation \\
\hline Media does not vary & $\begin{array}{c}\text { Adding a summary of learning } \\
\text { materials }\end{array}$ \\
\hline Less detailed learning strategies & $\begin{array}{l}\text { Improve PBL syntax guidelines for } \\
\text { teachers and students }\end{array}$ \\
\hline \multicolumn{2}{|c|}{ Media of Expert } \\
\hline Before evaluation & After evaluation \\
\hline $\begin{array}{l}\text { For PPT: } \\
\text { 1. Change Font Type }\end{array}$ & $\begin{array}{l}\text { 1. The font has been changed } \\
\text { to century font }\end{array}$ \\
\hline $\begin{array}{l}\text { 2. Improve the learning } \\
\text { objectives in the PPT }\end{array}$ & $\begin{array}{l}\text { 2. The objectives in the PPT are } \\
\text { changed to After participating } \\
\text { in learning through this } \\
\text { power point, students will be } \\
\text { able to provide solutions to } \\
\text { solving social problems using } \\
\text { various sociological concepts } \\
\text { and factual data }\end{array}$ \\
\hline
\end{tabular}

\section{Conclusion}

The results showed that from the expert test consisting of material, media and instructional design experts it can be stated that the learning design of Sociology Subjects with a problem-based learning model approach is feasible to use.

\section{References}

Al-Tabany, Trianto Ibdnu Badar. (2014). Designing Innovative, Progressive, and Contextual Learning Models: Concepts, Foundations, and Their Implementation in the 2013 Curriculum. Jakarta: Prenadamedia Group

Baharuddin. (2007). Learning \& learning theory. Yogyakarta: Ar-Ruzz Media

Basri, Hasan. (2015). New Paradigm of Learning Systems. Bandung: Faithful Library

Branch, Robert Maribe. (2009) Instructional Design: The ADDIE Approach. New York: Springer

Creswell, John W. (2010. Research Design: Qualitative, Quantitative, and Mixed Approaches. Yogyakarta: Student Library

Dalyono. (2005). Educational Psychology. Jakarta: rineka Cipta

Desmita. (2006) Developmental Psychology. Bandung: Rosdakarya

Dimyati and Mudjiono. (2015) Learning and Learning. Jakarta: Rineka Cipta

Hurlock, Elizabeth B. (2003). Developmental psychology. Jakarta: Erlangga

Johnson, Elaine B. (2012). Ctl (Contextual Teaching and Learning) Makes Teaching and Learning Activities Meaningful. Bandung: Kaifa 
Ngalimun. (2012). Learning Strategies and Models. Yogyakarta: Aswaja Pressindo

Rusman. (2012). Learning Models Developing Professionalism. Teacher Jakarta: Rajagrafindo

Rusmono. (2012). Learning Strategy with Problem Based Learning is necessary for

Increase Teacher Professionalism. Bogor: Ghalia Indonesia

Saifuddin. (2014). Management of Practical \& Theoretical Learning. Yogyakarta: Deepublish

Sani, Ridwan Abdullah. (2014). Scientific Learning for the Implementation of the 2013 Curriculum. Jakarta: Earth Literacy

Setyosari, Punaji. (2016). Educational Research and Development Methods. Jakarta: Prenadamedia Group

Suparman Atwi. (2014). Instructional Design. Jakarta: Erlangga

Shah, Muhibbin. (2008). Educational Psychology with a New Approach. Bandung: PT Remaja Rosdakarya

Sigit Mangun Wardoyo, Research-Based Learning, Jakarta: Akamedia Permata.

Simorangkir, F.M.A., and Sembiring, R.K.B. (2018). Effectiveness of Helped Mathematical Learning Media of Lectora Inspire on The Number Sense Ability of Fifth Grade Students of Elementary School in Substrate Materials. Budapest International Research and Critics Institute-Journal (BIRCI-Journal). P. 352-358.

Soehartono, Irawan. (2004). Social Research Methods A Research Technique in the Field of Financial Welfare and Other Social Sciences. Bandung: Youth Rosdakarya

Sugiyono. (2016). Educational Research Methods: Quantitative, Qualitative and R \& D Approaches. Bandung: Alfabeta

Surya, Hendra. (2011). The right strategy to achieve learning success. Jakarta: Elek Media Komputindo

Tutik Rachmawati \& .Daryanto. Learning Theory and Educational Learning Process. (Yogyakarta: Gava Media 2015). Pg 67

Wardoyo, Sigit Mangun. (2013). Research Based Learning. Jakarta: Akamedia Permata

Yamin, Martinis. (2013). New Paradigm of Learning. (Jakarta: Reference, 2013) p.9

Yusuf, Syamsu. (2004). Developmental Psychology of Children and Adolescents. Bandung: PT Remaja Rosdakarya

Zusmelia. Et al. (2015). Sociology Textbook of Economics. Yogyakarta: deepublish

https://hasilun.puspendik.kemdikbud.go.id/\#2019!smp!capai_nasional!99\&99\&999! T\&T\&T\&T\&1\&unbk!1!\&

Fristadi, Restu. (2015 Improving Students' Critical Thinking Ability with Problem Based Learning, National Seminar on Mathematics and Mathematics Education .UNY, ISBN. 978-602- 73403-0-5, Yogyakarta

Rickles, Michael L, et al. (2013) Assessing Change inStudent Critical Thinking for Introduction to Sociology Classes. Teaching sociology journal Volume: 41 issue: 3, page (s): 271-28: American Sociological Association

Wenita, Ade. (2012). Implementation of Active Learning Method Index Card Match to Increase Student Learning Activities in Learning Sociology Class Xi Ips 3 SMA Negeri 4 Yogyakarta Academic Year 2012/2013. Yogyakarta: Yogyakarta State University 